\title{
Pedagogical Conditions of the Formation of Value Attitude to Another Person in Teenagers of Comprehensive Boarding Schools
}

\author{
Filonenko Lesia \\ ORCID: https://orcid.org/0000-0002-1969-8387 \\ Postgraduate student \\ Vinnytsia Mykhailo Kotsubynskyi State Pedagogical University (Ukraine)
}

\begin{abstract}
This article gives a theoretically substantiated pedagogical conditions of the formation of a value attitude to another person in teenagers of boarding schools such as: the development and the implementation of the content, forms and methods of the formation of a value attitude to another person in teenagers of boarding schools; the involvement of teenagers of boarding schools to humane-oriented activities; the humanisation of relations within the system «pedagogue-student», «student-student»; the enhancement of the level of the readiness of teachers of boarding schools to the formation of a value attitude to another person in teenagers. The formation of a value attitude to another person in teenagers of boarding schools includes: the expansion of boarding schools teenagers' ethic knowledge about the respect to dignity, benevolence, equal rights, self-sufficiency, reasonableness; the formation of positive motivation among teenagers of boarding schools; skills of self-readiness and the readiness to a constructive dialogue. The development and the implementation of the content, forms and methods of the formation of a value attitude to another person was done in various ways such as: conducting educative hours, philosophical classes, movie discussions, the discussion of stories and books, a training, individual consultations, quizzes, talks, drawings exhibitions.

Methods: stories, explanations, ethic talks, pedagogical demand, a public opinion, exercises, models, duties, discussions, role, imitation games, narratives, the creation of educative situations. The involvement of teenagers of boarding schools to the humane-oriented activity aiming at the formation of a value attitude to another person was done by means of student self-governance. We used such forms as campaigns, events, concerts, team work for the sake of others, a project work, etc. The process of the humanisation of relations in the system «pedagogue-student», «student-student» embraced the following: the humanisation of relations among pedagogical faculty of a boarding school; the humanisation of an educational process; the humanisation of relations between teenagers of boarding schools.

The enhancement of the degree of the readiness of teachers of boarding schools to the formation of a value attitude to another person in teenagers was done while conducting the seminar «We are forming a value attitude to another person in teenagers of boarding schools» (lectures, interactive classes).

Keywords: teenagers, pedagogical conditions, the formation of a value attitude to another person, educators, a comprehensive boarding school.
\end{abstract}

Актуальність дослідження. У зв'язку з глибинними перетвореннями в соціальноекономічному та культурному житті українського суспільства, особливої гостроти набуває проблема морального виховання молодого покоління, а відтак і формування ціннісного ставлення до іншої людини.

Проблема формування ціннісного ставлення до іншої людини у молодого 
покоління розглядається в різних аспектах: гуманістичний підхід (К. Журба, В. Киричок, К. Чорна); особливості взаємодії з іншими людьми (А. Амонашвілі, І. Бех, І. Білецька, В. Білоусова, I. Бужина, О. Докукіна, Л. Канішевська, Г. Кирмач, О. Коберник, О. Третяк, Н. Щуркова та ін.).

Однак поза увагою науковців залишився такий аспект, як формування цүіннісного ставлення до іншої людини у підлітків шкіл-інтернатів, що стало метою нашої статті.

Виклад основного матеріалу. Найважливішими завданнями шкіл-інтернатів є: створення умов, які б забезпечували їм участь у всіх сферах соціальних відносин; формування соціальних умінь; допомога в особистісному та професійному самовизначенні; підготовка вихованців до самостійного життя [2, с. 293; 6; 7; 8; 11].

Аналіз психолого-педагогічної літератури, визначення стану сформованості ціннісного ставлення до іншої людини у підлітків шкіл-інтернатів дозволяє визначити педагогічні умови, які підвищують ефективність формування ціннісного ставлення до іншої людини у вищеназваного контингенту учнів та забезпечують їх реалізацію в найтіснішому взаємозв'язку.

Однією з педагогічних умов формування ціннісного ставлення до іншої людини є розроблення та впровадження змісту, форм і методів формування ціннісного ставлення до іншої людини у підлітків шкіл-інтернатів. Зміст формування ціннісного ставлення до іншої людини в підлітків шкіл-інтернатів включав: розширення етичних знань підлітків шкіл-інтернатів про повагу гідності, доброзичливість, рівноправ'я, виваженість, самодостатність; формування у підлітків шкіл-інтернатів позитивної мотивації; формування у підлітків шкіл-інтернатів навичок самопізнання та готовності до конструктивного діалогу.

Серед вербальних методів широко використовувалися етичні бесіди. Особливістю етичних бесід була їхня діалогічність, що давало змогу висловити власну думку усім учасникам. Етична бесіда також будувалася на зворотньому зв'язку та рефлексії, як показниках іï ефективності. Під час проведення етичної бесіди враховувалися моральні запити та потреби підлітків шкіл-інтернатів, проблеми, які вони намагаються вирішити, а також ті, що їх цікавлять, вікові особливості вихованців, гендерний склад. Важливо було, аби етична бесіда орієнтувала школярів на моральні цінності, спонукала до прояву ціннісного ставлення до іншої людини у реальній 
поведінці. Педагоги зважали на те, щоб тема етичної бесіди не лише була актуальною і цікавою для школярів, а й була пов'язана з життям, подіями шкільного життя, життєвим досвідом вихованців. При проведенні етичних бесід зверталася увага на логічне розкриття теми та іï практичне значення для кожного. Практика підтвердила ефективність використання елементів сократівської бесіди у 5-7-х класах та сократівської бесіди у 8-9-х класах. Застосування сократівської бесіди передбачало серію чітко сформульованих запитань, на які підлітки самостійно доходили до правильних висновків щодо необхідності проявів ціннісного ставлення до іншої людини. Так, з підлітками шкіл-інтернатів було проведено бесіди: «Як виявляти повагу до інших?», «Чи вміємо ми дружити?», «Коли піклуються про нас, коли піклуємося ми ?» (5 клас), «Вчимося виявляти співчуття і радість за інших», «Коли потрібна наша допомога?», «Будемо гуманістами» (6 клас), «Доброта зігріє світ», «Не будь байдужим», «Живемо серед людей» (7 клас), «Культура гідності сучасної молодої людини», «Спілкування і стосунки з однокласниками» (8 клас), «Ми творимо своє життя самі» (9 клас).

Свою ефективність довів також метод дискусії, який сприяв формуванню ціннісного ставлення до іншої людини у підлітків шкіл-інтернатів через виховання культури дискусії, навичок опонування, доведення своєї позиції, добір аргументів. Зокрема, з підлітками шкіл-інтернатів було проведено дискусії за наступними темами: «Бути собою чи бути як усі?», «Білі ворони» в колективі», «Хочу! Можу! Треба! Чи можливо їх узгоджувати?», «Доброта і егоїзм», «Якою має бути дружба?».

Наступною педагогічною умовою є залучення підлітків шкіл-інтернатів до гуманістично спрямованої діяльності з формування ціннісного ставлення до іншої людини.

Пристаємо до думки Канішевської, яка зазначає, що не кожна діяльність може бути визначена як сфера виховання. «Такими можуть вважатися лише ті їі різновиди, в яких діяльність дитини спрямовується на пізнання і перетворення навколишнього світу і самої себе, відбувається виховна взаємодія, і, як наслідок, вона оволодіває тими чи іншими елементами соціального досвіду, людської культури» [4, с. 95]. Соціальна діяльність може бути непомітною, але вона все одно залишається соціально значущою. 
Ця діяльність може здійснюватись один на один з книгою, у мріях, у розмовах і зізнаннях [3, c. 117].

У процесі дослідно-експериментальної роботи було використано такі види діяльності, спрямовані на виявлення ціннісного ставлення до іншої людини: навчальна допомога слабким учням (під час самопідготовки), залучення підлітків шкіл-інтернатів до суспільно значущих справ, а саме: допомога хворим, літнім людям, пенсіонерамодинакам, колективна праця для інших людей, участь у заходах до Дня захисту дітей, Дня інвалідів, Дня людей похилого віку; виготовлення привітань зі святами для учителівпенсіонерів, ветеранів; підготовка святкового концерту та виготовлення подарунків для молодших школярів, подарунки солдатам тощо.

Наступна педагогічна умова формування ціннісного ставлення до іншої людини у підлітків шкіл-інтернатів - гуманізащія взаємин у системі «педагог-учень», «ученьучень».

Нами було виокремлено наступні напрями гуманізації взаємин у системі «педагог-учень», «учень-учень»: гуманізація відносин у педагогічному колективі школи-інтернату, що полягала в гуманізації управління з боку керівництва закладу освіти; формування доброзичливої громадської думки; розвитку толерантних взаємин між педагогами; створення сприятливого психологічного клімату у школі-інтернаті; гуманізація освітнього процесу, яка полягала в індивідуалізації та диференціації навчання; співпраці педагогів та учнів у вирішенні питань організації життєдіяльності вихованців; залучення підлітків шкіл-інтернатів до гуманістично спрямованої діяльності; гуманізація взаємин між підлітками шкіл-інтернатів, що передбачає створення в школі-інтернаті атмосфери гуманності, взаєморозуміння; формування в особистості орієнтації на іншу людину, розуміння іiї почуттів, виявлення співчуття до іншої людини; уміння ставити інтереси іншої людини вище за свої; формування в учня здатності чинити опір власним негативним якостям.

Здійснюючи педагогічну підтримку, педагоги стимулювали у вихованців самопізнання своїх позитивних рис; формували моральні якості школяра у процесі оцінювання власної поведінки; акцентували увагу на позитивних вчинках учнів; підтримували ініціативу, активність [1, с. 219]. 
Підвищення рівня готовності вихователів шкіл-інтернатів до формування ціннісного ставлення до іншої людини у підлітків відбулося під час проведення семінару «Формуємо ціннісне ставлення до іншої людини у підлітків шкіл-інтернатів» (лекції, інтерактивні заняття).

Висновки. Одержані результати засвідчили істотне зростання кількості підлітків шкіл-інтернатів із високим і середнім рівнями сформованості ціннісного ставлення до іншої людини в експериментальній групі порівняно 3 контрольною. Динаміка рівнів сформованості ціннісного ставлення до іншої людини у підлітків шкілінтернатів для високого рівня - +11,39\%; середнього - + 21,95\%; низького - -33,34 \% .

Через що, проведене дослідження не вичерпує багатогранності теоретичних і практичних пошуків розв'язання проблеми. Подальшого вивчення i розвитку потребують такі питання, як то питання формування ціннісного ставлення до іншої людини в учнів шкіл-інтернатів інших вікових груп (молодші школярі, старшокласники).

\section{References}

1. Kanishevska L. V. Doslidzhennia problemy vykhovannia sotsialnoi zrilosti starshoklasnykiv shkil-internativ. [The research of the problem of fostering social maturity in senior students of orphan boarding schools]. Pedahohichnyi almanakh: zb. nauk. prats. Kherson KVNZ "Khersonska akademiia neperervnoi osvity", 2012. Issue 16. P. 213-220.

2. Kanishevska L.V. Doslidzhennia problemy pidhotovky starshoklasnykiv shkilinternativ do samostiinoho zhyttia. [The research of the problem of preparing senior students of orphan boarding schools to their own life] // Teoretyko-metodychni problemy vykhovannia ditei ta uchnivskoi molodi: zb. nauk. prats. Kirovohrad: Imeks - LTD, 2013. Issue 17, Kn. 1. P. 293-299.

3. Kanishevska L. V. Orhanizatsiia sotsialno-kulturnoi diialnosti starshoklasnykiv z formuvannia sotsialnoho dosvidu. [The organisation of social and cultural activities for senior students in order to form their social experience] // Teoretyko-metodychni problemy vykhovannia ditei ta uchnivskoi molodi : zb. nauk. prats. Kirovohrad : TOV "Imeks-LTD", 2010. Issue 14. Kn. 1. P. 116-124.

4. Kanishevska L. V. Pidhotovka starshoklasnykiv shkil-internativ do zhyttiediialnosti u vidkrytomu suspilstvi (vykhidni kontseptualni polozhennia). [Preparation of senior pupils of boarding schools for living in an open society (outgoing conceptual provisions)] // Teoretykometodychni problemy vykhovannia ditei ta uchnivskoi molodi : zb. nauk. prats Issue 15. Kn. 2 Kamianets-Podilskyi: Vydavets PP Zvoleiko D. H., 2011. P. 88-97.

5. Kanishevska L.V. Formuvannia zhyttievoi kompetentnosti pidlitkiv shkil-internativ [Formation of life skills of adolescents of boarding schools]. Novi tekhnolohii navchannia. 2006. No 44. P. 86-91. 
6. Pet'ko L.V. Vykhovnyi potentsial metodu sytuatsiinoho analizu ("Case study» method) u formuvanni profesiino oriientovanoho inshomovnoho navchalnoho seredovyshcha $v$ umovakh universytetu [Educational potential of the «Case study» method for the forming of the professionally oriented foreign language teaching environment in the conditions of university]. Naukovyi chasopys NPU imeni M.D.Drahomanova. Seriia 17. Teoriia i praktyka navchannia ta vykhovannia : zb. nauk. pr. Kyiv: Vyd-vo NPU imeni M.P.Drahomanova, 2015. Issue 27. P. 133-140.

7. Pet'ko L. V. Sotsialno-komunikatyvna aktyvnist pidlitkiv: teoriia $i$ praktyka [Monohrafiia]. [Social and communicative activity of adolescents: theory and practice [Monograph]. Kyiv: VMURoL "Ukraina", 2010. 268 p.

8. Filonenko Lesia. The peculiarities of forming value attitude to another person in teenagers of boarding schools. Intellectual Archive. - Toronto: Shiny World Corp. (Canada). 2018. (July/August). Vol. 7. No. 4. PP. 80-85. https://doi.org/10.32370/2018_07_80

9. Kanishevska L.V., Stadnik N.V. Theoretical aspects of the concept "responsibility" in works by foreign researchers. Perspectives of research and development: Collection of scientific articles. SAUL Publishing Ltd, Dublin, Ireland, 2017. P. 129-131.

10. Pet'ko Lyudmila. The "Case Study" Method as Means of Formation of a Professionally Oriented Foreign Language Teaching Environment in University Conditions. Intellectual Archive. 2015. Volume 4. Num. 4 (July). Series "Education \& Pedagogy". Toronto: Shiny World Corp. PP. 48-65.

11. Shkolna Maria. Pedagogical conditions for upbringing social maturity of students' agricultural colleges. Intellectual Archive. Toronto: Shiny World Corp. (Canada). 2017. September/October. Vol. 6. No. 5. PP. 79-85.

\section{Translation of the Title, Abstract and References to the Author's Language}

\section{УДК: 37.018.32 - 057. 87:17.022.1:316.454-043.83}

Філоненко Леся. Педагогічні умови формування ціннісного ставлення до іншої людини у підлітків загальноосвітніх шкіл-інтернатів.

У статті теоретично обгрунтовано педагогічні умови формування ціннісного ставлення до іншої людини у підлітків шкіл-інтернатів, а саме: розроблення і впровадження змісту, форм і методів формування ціннісного ставлення до іншої людини у підлітків шкіл-інтернатів; залучення підлітків шкіл-інтернатів до гуманістично спрямованої діяльності; гуманізація взаємин у системі «педагог-учень», «учень-учень»; підвищення рівня готовності вихователів шкіл-інтернатів до формування ціннісного ставлення до іншої людини у підлітків. Одержані результати засвідчили істотне зростання кількості підлітків шкіл-інтернатів із високим i середнім рівнями сформованості ціннісного ставлення до іншої людини в експериментальній групі порівняно $з$ контрольною, що свідчить про ефективність апробованих педагогічних умов.

Ключові слова: педагогічні умови, формування ціннісного ставлення до іншої людини, підлітки, вихователі, загальноосвітня школа-інтернат.

\section{Jimepamypa}


1. Канішевська Л. В. Дослідження проблеми виховання соціальної зрілості старшокласників шкіл-інтернатів. Педагогічний альманах : зб. наук. праць. Херсон КВНЗ «Херсонська академія неперервної освіти», 2012. Вип. 16. С. 213-220.

2. Канішевська Л. В. Дослідження проблеми підготовки старшокласників шкілінтернатів до самостійного життя. Теоретико-методичні проблеми виховання дітей та учнівської молоді: зб. наук. праць. Кіровоград: Імекс - ЛТД, 2013. Вип. 17, Кн. 1. C. 293-299.

3. Канішевська Л. В. Організація соціально-культурної діяльності старшокласників 3 формування соціального досвіду. Теоретико-методичні проблеми виховання дітей та учнівської молоді: зб. наук. пр. Кіровоград: ТОВ «Імекс-ЛТД», 2010. Вип. 14. Кн. 1. С. 116-124.

4. Канішевська Л. В. Підготовка старшокласників шкіл-інтернатів до життєдіяльності у відкритому суспільстві (вихідні концептуальні положення). Теоретико-методичні проблеми виховання дітей та учнівської молоді: зб. наук. праць Вип. 15. Кн. 2 Кам’янець-Подільський: Видавець ПП Зволейко Д. Г., 2011. С. 88-97.

5. Канішевська Л. В. Формування життєвої компетентності підлітків шкілінтернатів. Нові технологї̈ навчання. 2006. № 44. С. 86-91.

6. Петько Л.В. Виховний потенціал методу ситуаційного аналізу («Сase study» method) у формуванні професійно орієнтованого іншомовного навчального середовища в умовах університету. Науковий часопис НПУ імені М.Д.Драгоманова. Серія 17. Теорія i практика навчання та виховання : зб. наук. пр. ; за ред. академіка В.І.Бондаря. Київ: Вид-во НПУ імені М.П.Драгоманова, 2015. Вип. 27. С. 133-140.

7. Петько Л. В. Соціально-комунікативна активність підлітків: теорія і практика [Монографія]. К. : ВМУРоЛ «Україна». 2010. 268 с.

8. Filonenko Lesia. The peculiarities of forming value attitude to another person in teenagers of boarding schools. Intellectual Archive. - Toronto: Shiny World Corp. (Canada). 2018. (July/August). Vol. 7. No. 4. PP. 80-85. https://doi.org/10.32370/2018_07_80

9. Kanishevska L. V., Stadnik N. V. Theoretical aspects of the concept "responsibility" in works by foreign researchers. Perspectives of research and development: Collection of scientific articles. SAUL Publishing Ltd, Dublin, Ireland, 2017. P. 129-131.

10. Pet'ko Lyudmila. The "Case Study" Method as Means of Formation of a Professionally Oriented Foreign Language Teaching Environment in University Conditions. Intellectual Archive. 2015. Volume 4. Num. 4 (July). Series "Education \& Pedagogy". Toronto : Shiny World Corp. PP. 48-65.

11. Shkolna Maria. Pedagogical conditions for upbringing social maturity of students' agricultural colleges. Intellectual Archive. Toronto: Shiny World Corp. (Canada). 2017. September/October. Vol. 6. No. 5. PP. 79-85. 